\section{Innsiktsfullt evolusjonsperspektiv på menneskehjernen}

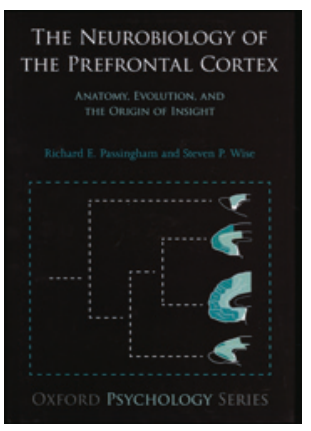

Richard E. Passingham, Stephen P. Wise The neurobiology of the prefrontal cortex Anatomy, evolution, and the origin of insight. 399 s, tab, ill. Oxford: Oxford University Press, 2012. Pris GBP 50

ISBN 978-0-19-955291-7

Hva er særegent ved menneskets hjerne? Hva kan forklare kvantespranget i fleksibilitet og læringsevne fra våre nærmeste primatslektninger? Passingham \& Wise argumenterer for at en hovedforklaring ligger i en særegen utvikling av prefrontalcortex (dvs. de delene av frontallappen som ligger foran de motoriske områdene). De underbygger sin argumentasjon hovedsakelig med en grundig og analytisk gjennomgang av forskningsresultater fra ulike typer av forsøk med aper og med kunnskap om primatenes evolusjon. Til tross for ny innsikt oppnådd med metoder for funksjonell hjerneskanning av mennesker gir dyreforsøk mulighet til et helt annet presisjonsnivå både i problemstillinger og resultater. Det gjelder både anatomi, nevropsykologiske undersøkelser med kontrollerte lesjoner og avansert elektrofysiologisk registrering hos våkne primater.

De to har solid bakgrunn fra egen forskning for oppgaven de har påtatt seg. De har begge nådd alderen hvor de har trukket seg tilbake fra aktiv forskning og kan tillate seg et videre blikk og dristigere spekulasjoner enn det som er vanlig blant forskere. De stiller to spørsmål i tillegg til dem som vanligvis stilles i bøker av denne typen: Hvorfor (ikke bare hvordan) prefrontalcortex utfører sine spesielle oppgaver (biologisk mening) og hvordan det kom til å bli slik (evolusjon). En av deres hypoteser er at da prefrontalcortex utviklet seg hos tidlige primater for å løse spesifikke miljømessige utfordringer, skjedde det ved utvikling av et nytt, «general-purpose» læringssystem.

Forfatternes agenda er altså å forstå de helt grunnleggende oppgavene som den menneskelige prefrontalcortex utfører. For dette formålet bruker de data fra en omfattende forskningslitteratur (fra anatomi til psykologi og evolusjon) som blir detaljert presentert og analysert med forståelse som siktemål. Hele veien gjennom teksten oppsummeres foregående argumentasjon i enkelt formulerte konklusjoner og påstander. Hvert av de ti kapitlene er dessuten innledet med en kort oversikt, og kapitteltitlene er også til hjelp for å se hva som er hovedtema.

Boken forutsetter forkunnskaper om hjernens anatomi, og med den store mengden forskningsresultater som presenteres kreves det en innsats av leseren for å følge med $\mathrm{i}$ argumentasjonen. Men det hjelper at forfatterne er uvanlig dyktige til å sette ting i sammenheng før de går i dybden. At de avslutter avsnitt og kapitler med lettfattelige spissformuleringer hjelper også. Alt i alt gir The neurobiology of the prefrontal cortex en sjelden mulighet til innsikt i det biologiske grunnlaget for unikt menneskelige egenskaper. Det skjer noe når erfarne forskere tar helheten og detaljene like alvorlig.

\section{Per Brodal}

Institutt for medisinske basalfag

Universitetet i Oslo

\section{Oversiktlig håndbok om akuttmedisin}

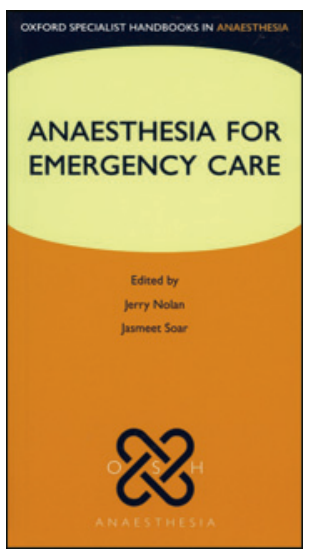

Jerry Nolan, Jasmeet Soar, red.

Anaesthesia for emergency care

399 s, tab, ill. Oxford: Oxford University Press, 2012. Pris GBP 35

ISBN 978-0-19-958897-8

Denne hendige håndboken er utgitt $\mathrm{i}$ serien «Oxford specialist handbooks» og tar for seg anestesi ved akutte tilstander. De 16 kapitlene er skrevet av de to redaktørene sammen med 46 anestesikolleger fra Bristol School of Anaesthesia. Den bygger således på britisk tradisjon i akuttmedisin og henvender seg til legestudenter og leger under spesialisering $i$ anestesiologi. Også ferdige spesialister vil kunne ha nytte av den som en ren oppslagsbok, men med det forbehold at vi i Norge i stor grad bruker amerikanske retningslinjer. Det gis kortfattete, konsise råd og veiledning for medisinsk håndtering og anestesi i akutte situasjoner på sykehus og og prehospitalt.

Forfatterne har strukturert innholdet i to deler hvor første del på om lag 50 sider, dekker generelle og grunnleggende emner. Utover anamnese og preoperativ vurdering omtaler de videre vaskulær tilgang, væsketerapi og smertebehandling. Bruk av ultralyd angis som rutine ved punksjon av v. jugularis interna og v. femoralis. Prehospitalt kan vel ultralydveiledet punksjon være vanskelig å gjennomføre.

Andre del - over 300 sider - dekker hele akuttmedisinen. Det er et ambisiøst prosjekt som lykkes gjennom grundig gjennomarbeidede kapitler. Det kortfattede innholdet er oversiktlig presentert. De punktvise rådene om behandlingsforslag og medisinske tiltak formidles klart og presist $i$ en didaktisk form og er basert på anbefalinger fra retningslinjer nedfelt i britiske medisinske fagmiljøer.

I omtalen av smertebehandling til barn er det tatt med doseringsforslag for både intravenøs og peroral administrering av paracetamol. Opioid dosering til barn er angitt etter protokoll for British Royal Hospital for Children (BRHC). Problematikken omkring akutt luftvei hos barn, fra symptom til diagnose og behandling, er omtalt $i$ et godt og oversiktlig kapittel. De anbefaler ved slike tilstander gassinnledning med sevofluran, som er en gullstandard. Men de nevner - riktignok i parentes - også halotan til gassinnledning. Halotan ble faset ut i 1980- og -90-årene av henholdsvis isofluran og sevofluran, og er avregistrert i Norge og ikke i bruk hos oss.

Et siste omfattende kapittel omhandler anestesiologiske akuttsituasjoner som livstruende vanskelig luftvei, mislykket intubasjon ved uventet vanskelig intubasjon, aspirasjon til lunger, anafylaksi og malign hypertermi. Det understrekes igjen hvor nødvendig det er å kunne det medisinske håndverket også i akutte situasjoner og ha kunnskap om tilgjengelig utstyr, hvor det finnes og hvordan det brukes. Disse anbefalingene bygger på britiske «Difficult Airway Guidelines» og flytdiagram.

Hvert kapittel avsluttes med referanser og forslag til videre lesning. Det er også plass til egne notater etter hvert kapittel og helt bakerst. Denne lille håndboken med sitt praktiske lommeformat er på tross av sin størrelse overraskende innholdsrik og rommer viktige anbefalinger og råd om behandling $i$ akuttmedisin. Den vil være nyttig for anestestesileger på vakt $\mathrm{i}$ akuttmottaket og på operasjonsstuen.

\section{Sidsel Hetland}

Oslo 